\title{
大正・昭和初期の大檑川改修による宍道湖の環境変化と住民の共生過程に関する研究
}

\section{The symbiosis with environmental change of the Shinji lake by river works in 1930s-1940s}

\author{
島谷幸宏* 皆川朋子* \\ Yukihiro SHIMATANI*, Tomoko MINAGAWA*
}

\begin{abstract}
The Sinji lake is the $6^{\text {th }}$ biggest lake in Japan and very famous for corbicula production. The Shinji lake is connected to sea trough the Ohashi River and the Naka lake. The river works of the Ohashi had done in 1924-1942. The river works had caused to drastic environmental change to the Shinji Lake. Fish fauna had changed from fresh water fish to blackish fish. People surprised at the change at first but they had become familiar with new environment. Because later ecosystem is much richer than former one But they need over 20 years until being familiar with the new environment.
\end{abstract}

Keywords: human impact, blackish lake, corbicula, environmental change, fish fauna

\section{1.はじめに}

宍道湖は面積日本第6位、ヤマトシジミの生産量日本1 位を誇る日本を代表する汽水湖である。しかし元々汽水 湖であったわけではなく緡文期は海水湖であり、その後、 斐伊川による埋積、流路の変遷により江戸時代初期に一 旦淡水化し、佐陀川の開削 (江戸中期)、大橋川改修(大 正末期から昭和初期)により汽水化したことはよく知られ ている。 川の改修による宍道湖の魚介類相の変化、宍道湖汽水 化に伴う塩害その後の住民の環境変化への順応の過程 を新聞等の資料に基づきたどり、大規模な環境変化に地 域住民がどのように共生していくのかを考察する。

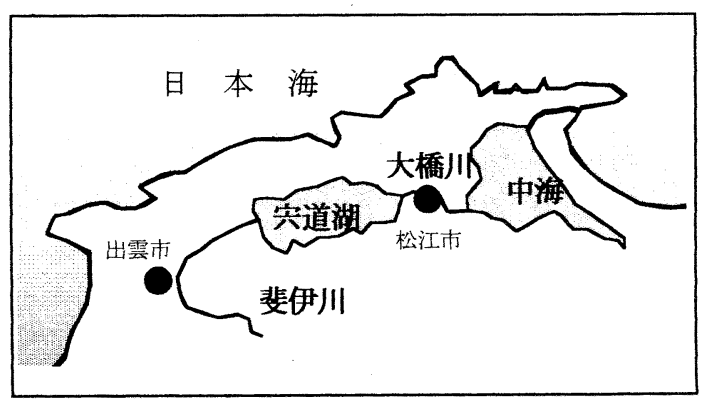

図一1 宍道湖位置図

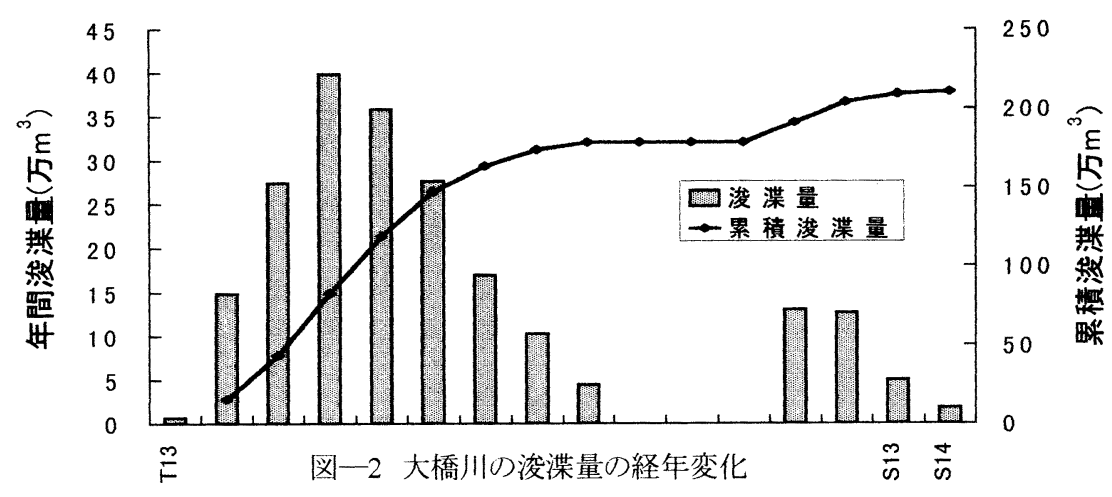

* 建設省土卜研究所 環境部 河川環境研究公

River Environment Division, Pubic Works Research Institute, Ministry of Construction 


\section{2. 大橋川改修の概要}

明治 26 年、台風による豪雨により穴道湖の水位は松江で最高水位 $2.73 \mathrm{~m}$ を記録し、全市に汇濫し約 8000 戸が浸水するという大洪水を被った。そのため内務省では大正13年から昭和14年にかけて、突道 湖の排水を良くし、加えて舟運の便を図るため大橋川の搪幅 $(72 \mathrm{~m}$ )および浚渫(水深 $4.5 \mathrm{~m}$ )を行った2)。 図一2 に浚渫量の経年変化を示した。総浚渫量は 210 万 $\mathrm{m}^{3}$ 、浚渫の最盛期は大正 15 年度から昭和 4 年度で、年間の最大浚渫量は昭和 2 年の約 40 万 $\mathrm{m}^{3}$ である。また川幅を約 3 倍程度に大きく広げた区間 は川津工区 (中海河口から約 $4 \mathrm{~km}$ から $6 \mathrm{~km}$ にかけて)、その浚渫は昭和 3 年度から 4 年度にかけてであ る。浚渫の影響が魚類相に現れ始めるのは、その区間が浚渫された昭和 4 年頃よりである。

\section{3. 魚類相の変化}

新聞記事により魚類相の変化を追跡する。資料は松陽新聞、山陰新聞の大正元年から昭和16年の記 事および島根新聞 (山陰新聞と松陽新報合併)の昭和 17 年 26年の記事である。なお松陽新聞の大正 4年〜昭和 2 年 3 月までの記事は国会図書館での資料は欠損しているので参考にできていない。

大橋川改修前の宍道湖は夏場の渴水時期を除き淡水湖であった ${ }^{3)}$ 。……浚渫前においては中海より 逆流する海水は夏季の渇水時期を除くと、殆ど宾道湖には逆流せず大橋川さへ塩分を認めることはなか った……片したがって大橋川改修以前の宍道湖は淡水魚が優先しており、渴水時期の塩水の遡上で 汽水魚も宾道湖に進入していたものと推測される。实道湖における昭和 3 年の漁獲高 4 ( 水揚げ額の

多い順に並べるとウナギ(18000 円)、スズキ、ワカサギ、シラウオ、コイ、ハゼ、エビ、シジ(1000円)、コ) シ口の順になっている。淡水魚と汽水魚ともに漁獲高の上位を占めていることがわかるが、現在のようにシ 泛が漁獲高の大半を占めていたわけではない。ちなみに漁獲量べースで現在と比較してみると、昭和 3

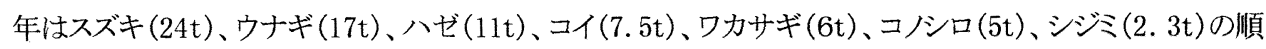

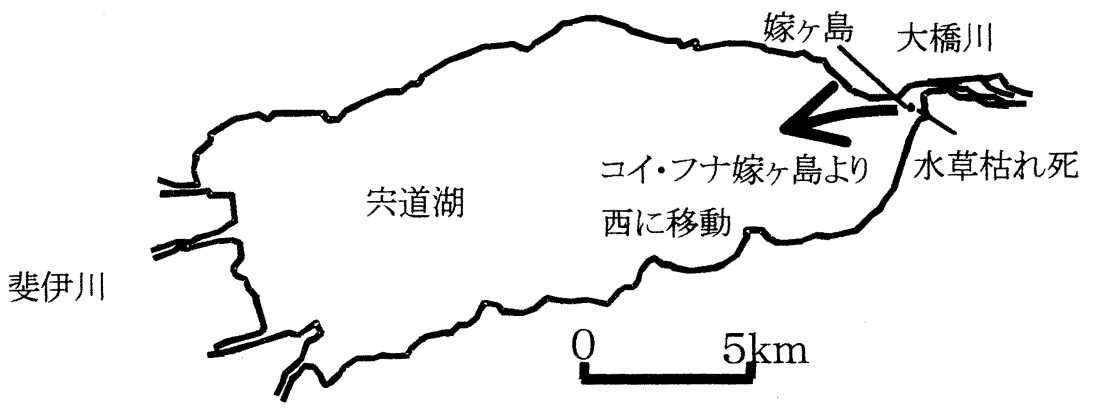

図一3 昭和 4 年の魚類および水草の変化

(昭和 4 年 11 月 30 日 松陽新報 夕刊記事を基に作図)

で、平成 5 年内水面漁獲量統計によると漁獲量の多い順にシジミ $(8730 \mathrm{t}) 、$ フナ $(210 \mathrm{t}) 、$ 、ワギ $(190 \mathrm{t}) 、$ エビ類 $(51 \mathrm{t}) 、 コ イ(18 \mathrm{t}) 、$ 、焦 $(10 \mathrm{t}) 、$ 、ラウオ $(9 \mathrm{t})$ となり現在の方が全体的に漁獲量は多く、なかでも シジミ゙圧倒的に増加していることが分かる。

魚類相の変化が新聞に掲載され始めるのは昭和 4 年の秋からである。大橋川の浚渫により宍道湖に塩 水が流れ込み大橋川では中海で見られる海魚類のほとんどのものがみられ、コイやフナの生息域は狭め られ宍道湖内にある嫁ヶ島以西に移動し、嫁ヶ島以東では水草は枯死し中海と同じ魚類が見られると島 根県水産試験場の調査結果に基づき報じている。 ${ }^{31}$

昭和5年になると両新聞に䔡類の変化に関する記事が何度も掲載される。

そのころの新聞記事には次のように書かれている。 
「突道湖相の変化は大橋川浚渫以来急速に現れつつあるので島根県水産課に於いては湖上に実地 調查を行っているが同調查に於いて現在までに知方れた湖水の変化は次の如くである。…..最近半箴

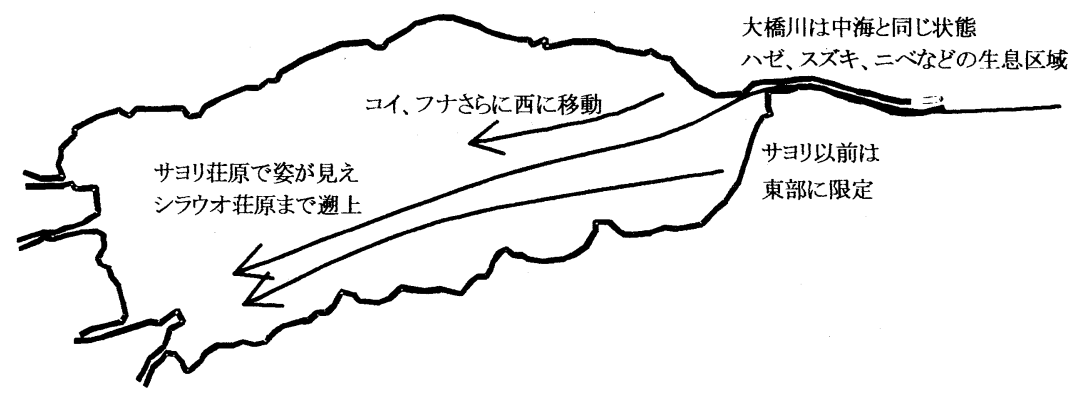

図-4 昭和 5 年の魚類の移動

(昭和 5 年 10 月 26 日 松陽新報夕刊記事を基に作図)

性のもつが増加しその生息範囲は拡大しつつあり、鯉、鮒の如き魚類は益々西に移動し東部には頗る尠 少となってきている。……鬼に角今年に入って湖水漁業に於いて顕著なる变化として実際の漁労に現れ て来たのは白魚でこれまで殆ど獲れなかった荘原方面まで遡上したこと、湖水の東部の一隅にしかいな かったさよりが同じく荘原付近にまで姿を見せるようになった……鯉が例年約四万貫、五万円の漁獲をあ げていたのに昨年は三割を减じている…....5

昭和6年になるとシジミの移殖が話題になる。「……名物であった蜆が絶滅に瀕している……北松江、 嫁が島見通し線上の湖水に五百坪の占有漁場を設定し、兵庫県城崎郡丸山川産 (現円山川)のシジ 一石を移殖散布することとし 11 月 26 日これを施行した。しかして丸山川さんは全国的に有名なシジミで 成長後は径一寸以上に達し而も肉太りの頗る良い美味のものである……」可このように宍道湖水産会は 11月26日兵庫県城崎郡円山川 (当時丸山川) のシジミ1石を北松江と嫁ヶ島を結ぶ線上に移殖散布し た ${ }^{6)}$ 。翌年には大橋川漁業組合もシジミの復活増殖を図るために円山川産のシジミを散布した ${ }^{7)}$ 。昭和7 年の記事によると4ケ月の間の成長は頗る良く湖水に適していることが判明し円山川産のシジミの放流が 継続されることとなった ${ }^{8)}$ 。現在、突道湖は全国第一位のシジミの生産を誇っているが、当時は円山川の シジミの方が著名で、一時は絶滅の危機に瀕し他河川から移殖したといら事実は、非常に興味深い。シ ジミの生産が大幅に増加するのは昭和 16 年からである。

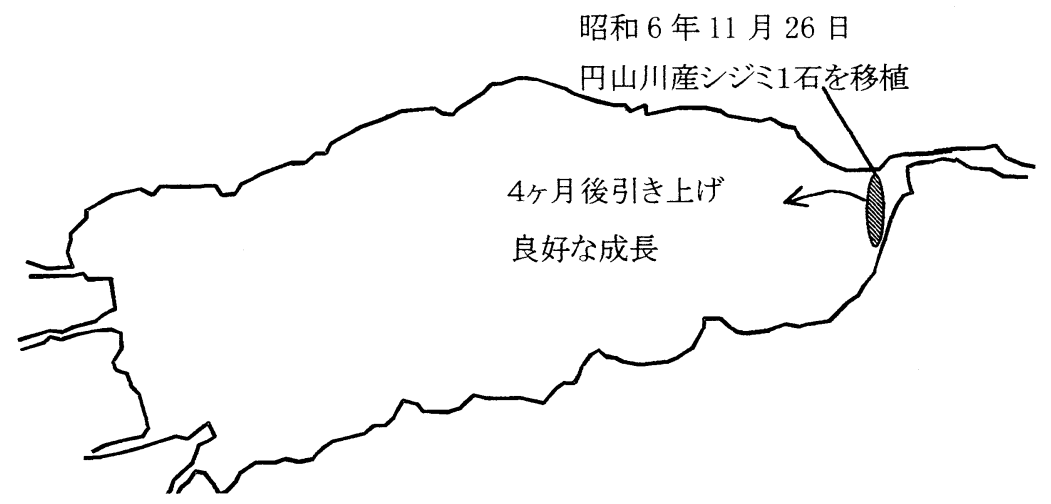

図一5 昭 6 年のシジミの移殖

（昭和 6 年 11 月 27 日朝刊 昭和 7 年 1 月 13 日 松陽新報を基に作図) 
また昭和 6 年には大橋川改修による淡水魚への影響対策をどうするかといら記事が見られる。見出しの みを列挙すると「水質がかは、、生息区域に変化 宾道湖の魚族西に移動 全国と協調して県で原因調 查」9「汐水が逆流して 淡水魯が姿を消す 松江で人工養鯉事業の声 大橋川浚渫と共に時代移る」 ${ }^{10)}$ 「宾道湖の海水化養殖で救い出す 東部に赤貝西部に蜆 将来は一名物たらしめる」11などである。

一方、昭和 7 年になると口カサギ、シラウオ、スズキ、ハゼなど汽水魚の豊漁記事がみられる。例えば「宾 道湖の名産すずきが俄かに襲った過日の大荒れに珍しい大漁であった……ぼらの入網も頗る多くはぜも 網に溢れる盛漁振りを示し引き続き下りはぜは漁獲され大橋川漁民はほくほくものである。」

さらに昭和10年、改修前は斐伊川等の河川、湖岸西部で産卵し中海まで下り、その後、穴道湖まで遡 上していたワカサギとシラウオは、最近は中海まで下るものは僅かで多くは宍道湖で生息し、宍道湖特に

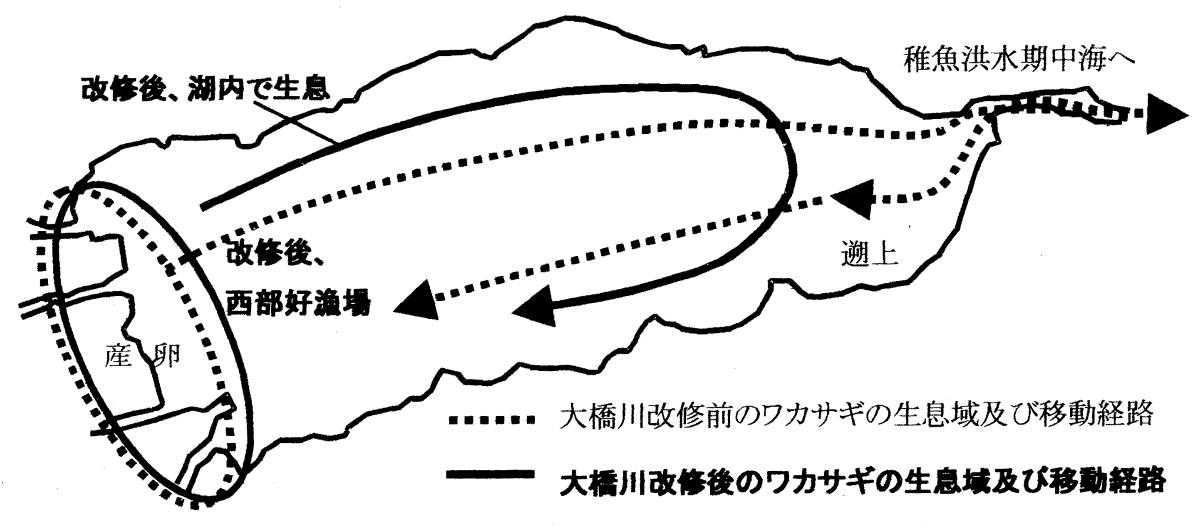

図一6 大橋川改修前後のワカサギの生息域の変化

（昭和 10 年 2 月 17 日 松陽新報夕刊に基づき図化）

西部が好漁場になり中海、大橋川の漁獲は激堿したと報じられている。「……橋川の改修以来の棲息 については引きつづき県水産課において調查を行っているがそれに依れば……公魚 (わかさぎ) =湖岸西 部並びに斐伊川等の河川に河川即ち洪水において産卵し、稚魚となって中海に下り更に大橋川を逆上 して湖水に入る性質を有していたが、最近大橋川の改修によって湖水が海水化して来たので中海への 下降は一部に止まり多くは湖水に棲息のまま成長することが明らかとなった。……每＝公魚と略同様な 性条であり、中海への稚魚降下は殊に強く、秋季より初冬にかけて下り、早春道上したものであるが、最 近これが著しく減じて公魚の如く湖水に腰を据えるものが大部分となってきた、このため中海方面及び大 橋川の漁獲は激減し、漁場として期待出来なくなりしかも従来湖西部は殆ど漁獲なかったものが近時好 漁場は西部に移っている。」 ${ }^{13)}$

以上のように大橋川の改修が始まってから5年程度を経過した昭和 4 年頃より、宍道湖の魚類相は淡水 魚中心から汽水魚が中心となってくる。このような変化が生じた当初は、漁民に不安が広がるが、汽水魚 の漁獲が増え、昭和 7 年頃からその不安は消えていっていることが読み取れる。

\section{4. 塩害の頻発}

宍道湖では渴水時には大橋川の改修以前から農業取水に対する塩害が生じていた。たとえば、大正 1 4年の記事では、「例年夏季は早天に際して大橋川に潮が逆入し稲作に被害を蒙らしめるが本年も二三 日前から此の現象が見え既に大橋川の各支川はもとより穴道湖にまで潮が入り込んでいる然しその程度

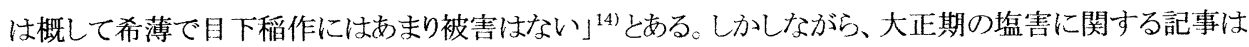
殆どなく、塩害は恒常的なものではなかったと考えられる。

大橋川の浚渫が進んだ昭和 4 年以降、農業に対する塩害が恒常的になる。表一1に大正末期から昭和 10 年までの塩害に関する記事を示した。5、6月が少雨の年は、6月に塩害の記事が掲載され、農業に被 
害を及ぼしている。その原因については、日照りと共に斐伊川・大橋川の改修及び境港の築造が原因と 認識されていた。

表一1 大正末期から昭和10年までの塩害に関する記事

\begin{tabular}{|c|c|c|c|c|c|}
\hline \multirow{2}{*}{ 年号 } & \multirow{2}{*}{ 塩害に関寸る記事の要約 } & \multicolumn{4}{|c|}{ 潅溉期の月間雨量 (mm) } \\
\hline & & 5月 & 6月 & 7月 & 8月 \\
\hline 大正 14 年 & $\begin{array}{l}\text { •三三日前から大橋川に潮が逆流、被害が出るほどではない。（山 } \\
\text { 陰 } 6 \text { 月 } 2 \text { 日） }\end{array}$ & 218 & 220 & 159 & 49 \\
\hline 大正 15 年 & $\begin{array}{l}\text { •干天にて大橋川沿岸では塩水のため水取りが出来ない。対策を } \\
\text { 講ずるための基本調查を県耕地課が実施。(山陰 } 6 \text { 月 } 26 \text { 日) }\end{array}$ & 183 & 53 & 150 & 125 \\
\hline 昭和 2 年 & $\begin{array}{l}\text { ・15 日に小雨があっただけで、前後数十日にわたって日照り。海 } \\
\text { 水の逆流も嫁が島周辺まで来潮し内堀一体も塩水となり潅湛に用 } \\
\text { をなさない。(松陽 } 6 \text { 月 } 28 \text { 日) }\end{array}$ & 94 & 38 & 353 & 231 \\
\hline 昭和 4 年 & $\begin{array}{l}\text { •大橋川から宍道湖に潮が逆流し沿岸農家苦しむ。（松陽 } 6 \text { 月 } 30 \\
\text { 日） }\end{array}$ & 108 & 89 & 79 & 73 \\
\hline 昭和 5 年 & 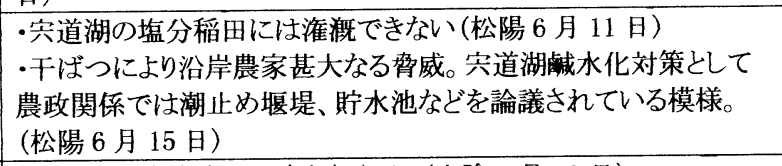 & 68 & 505 & 176 & 153 \\
\hline 昭和 9 年 & $\begin{array}{l}\text { •大橋川沿岸塩害その度を加える。(山陰 } 6 \text { 月 } 23 \text { 日） } \\
\text { •県において盍害苦を救うための塩害根本調查。(松陽 } 9 \text { 月 } 19 \text { 日) }\end{array}$ & 47 & 87 & 231 & 135 \\
\hline 昭和 10 年 & $\begin{array}{l}\text { 塩害対策の必要性を説く記事や農家の陳情に関する記事 多数 } \\
\text { (山陰 } 3 \text { 月 } 1 \text { 日、 } 6 \text { 月 } 15 \text { 日、 } 8 \text { 月 } 1 \text { 日、 } 8 \text { 月 } 9 \text { 日、 } 9 \text { 月 } 10 \text { 日、 } 10 \\
\text { 月 } 1 \text { 日、 } 12 \text { 月 } 4 \text { 日、松陽 } 7 \text { 月 } 5 \text { 日、 } 8 \text { 月 } 9 \text { 日) }\end{array}$ & 69 & 197 & 177 & 206 \\
\hline
\end{tabular}

注) 山陰: 山陰新聞 松陽: 松陽新報

例えば昭和 9 年の記事に依れば、「斐伊川の改修と境港の筑造、大橋川浚渫等のため湖岸地方より大 橋川沿岸にかけての塩害は著しく激甚となり、耕作に一大影響を来し農民は非常に苦境に至り、これが 調査を要望していたが県に於いて塩害調査の必要性を認めもいよいよ今年度から着手することになった m m n 境港の突堤により中海の水位が上昇を来したことは京都帝大理学部豊原氏の調査によっても明瞭 であり、大橋川の浚渫と斐伊川の改修はこれによって更に湖水と中海の落差を短縮、そのため海水は満 汐時に於て逆流を来し大橋川付近より湖岸一帯、佐太川沿岸は何れも激甚なる被害を受けるに至ったも

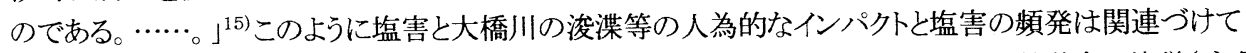
捉えられている。塩害対策として宍道湖の淡水化が昭和 12 年提案され、昭和 14 年県議会で決議され国 へ陳情された。大橋川改修以前はもともと穴道湖の塩分濃度は高くなく、人為的インパクトによって塩害 がもたされたといら認識が、塩害対策として宾道湖の淡水化案が農業サイドから提案されてきた要因の一 つであったと考えられる。

\section{5. 穴道湖の汽水環境との共生に関する考察}

以上のような環境変化、そして塩害の頻発の中で、地域住民は实道湖の汽水環境になじんでいった。 その様子を見てみる。昭和 16 年にはシジミ、スズキ、ハゼ、ワカサギの豊漁の記事が相次ぐ。 ${ }^{16) 17718) こ れ ~}$ らの記事に共通しているのは大橋川の浚渫などによる汽水化の影響と関連付けた記事が一切ないことで ある。この時点で地域が汽水環境になじんできたことが伺える。昭和 24 年に梥道湖を淡水化するための 調査が農林省で実施されたが、汽水生態系を維持するために漁民と観光業者が反対し、淡水化は実現 しなかった。 ${ }^{19) 201}$ 大橋川の浚渫事業が始まってから 26 年、魚類相に変化が出始めて約 20 年を経て汽水 生態系が地域の環境資源として定着し、認知されたことを示している。

以上のような宾道湖の環境変化と人々の共生の過程についてまとめてみる。

(1)大橋川改修等による宾道湖の環境変化は淡水湖 (弱い汽水湖)から汽水湖への環境変化であり昭和 4 年頃より魚類相の変化、農業への塩害といら現象しして現れた。

(2)魚類相の変化は汽水化に伴い速やかに変化し、淡水魚は西に移動し、汽水魚が優先するようになっ た。このよな魚類相の変化は 2,3 年といら短期間でおこった。 
(3)シジミについては一時絶滅の危機に瀕したが円山川からの放流なども行われ、昭和 16 年頃より漁獲量 が急増した。

(4)このような淡水魚から汽水魚への変化に、当初、漁民はとまどったが、昭和 7 年頃より汽水魚の漁獲量 が多くなったこともあって淡水魚が減少したことの危機感の声はあまりあがらなくなった。すなわち、魚類 相の変化が起きてから、わずか 4 年ほどで漁業的には落ち着きはじめた。

(5)一方、農業サイドでは塩害の問題が生じ、元々の環境が淡水的であったこともあり、宍道湖の淡水化が 塩害対策の有力な案として提案されるようになった。

(6)昭和 24 年に現在の汽水環境を保全するために、漁業及び観光サイドから宍道湖の淡水化案が否定さ れる。この時点で汽水環境が重要であるといら認識が定着してきたことを示している。

以上のように、实道湖の汽水環境に地域住民が共生するのにおおむね 20 年の歳月を要している。宍 道湖の場合、歴史的に海水湖 $\rightarrow$ 汽水湖 $\rightarrow$ 淡水湖 $\rightarrow$ 汽水湖とその環境は大きく変遷してきており、元々の 環境は何かと言うことを一概に言うことは難しい。しかしながら江戸時代初期以降 300 年以上続いていた 淡水湖的環境から汽水湖への変化は、地域住民にとってはドラスッテイックな変化であったはずである。 （正確には佐陀川の改修により江戸末期に若干、塩水が宾道湖にも流入するようになっていた）しかしな がら現在、宾道湖の汽水環境は穴道湖ならではの、地域にとってかけがえのない環境として定着してい るように思われる。大規模な環境の変化後、シジといら有用種の生産量が増えるなど生態系が豊かにな ったことが、地域の人々に受け要られた主たる要因であると考えられる。豊かな生態系が生まれたとは言 え、宍道湖の場合、新しい環境になじむのに 20 年といら月日が必要であった。

土木事業は環境に大きな影響を与えうる。ここで研究した宍道湖の事例は改変後の生態系が豊かであ るといらことが、改変が受け入れられるのに重要であり、しかも受け入れられるまでには 20 年といら時間が 必要であったことが明らかになった。

\section{6. おわりに}

宍道湖の生態系は大橋川の改修によって大きく変わった。現在、宍道湖の象徴となっているヤマトシジ ミも円山川から移入したものである可能性も否定できない。現在では、色々な経緯を経て、このような大き な生態系の変化に地元はすっかりなじんでいるように見える。シシミが有用種であったこともなじみやすか った理由の一つと思われる。ここでは人為的インパクトと生態系の変化そしてそれに対する人間の共生の 過程を宾道湖を事例に追った。

\section{参考 - 引用文献}

1) 德岡隆夫ほか(1990)、中海、宾道湖の地史と環境変化、地質学論集、,36, 15-34.

2) 建設省出雲工事事務所 (1995) 斐伊川史

3 ) 松陽新報: 昭和 4 年 11 月 30 日、朝刊

4) 同: 昭和 4 年 2 月 20 日、朝刊

5 ) 同: 昭和 5 年 10 月 26 日、夕刊

6) 同: 昭和 6 年 11 月 27 日、朝刊

7 ) 同: 昭和 7 年 1 月 31 日、朝刊

8 ) 同: 昭和 7 年 3 月 30 日、夘

9 ) 同: 昭和 6 年 6 月 20 日、朝刊

10) 山陰新聞: 昭和 6 年 6 月 24 日

11）松陽新報：昭和 6 年 11 月 10 日、朝刊

12) 同: 昭和 7 年 11 月 11 日、刊

13) 同: 昭和 10 年 2 月 17 日、多刊

14) 山陰新聞 : 大正 14 年 8 月 9 日、朝刊

15）松陽新報：昭和 9 年 9 月 19 日、朝刊

16）同：炤和 16 年 11 月 12 日

17) 同: 昭和 16 年 11 月 23 日

18）同：昭和16年12月 18 日

19）島根新聞:昭和 24 年 2 月 13 日

20）川上誠一:宾道湖·中海の淡水化事業と住民運動、水質污濁研究、Vol.11,No.1,1988 